\title{
The protracted development of the continent-ocean transition in Afar
}

\author{
Ian D. Bastow ${ }^{1 \star}$ and Derek Keir ${ }^{2 \dagger}$
}

\begin{abstract}
Continental breakup and the transition to seafloor spreading is characterized by extensional faulting, thinning of the lithosphere and, at magmatic margins, voluminous intrusive and extrusive magmatism ${ }^{1-4}$. It is difficult to discriminate between different mechanisms of extension and magmatism at ancient continental margins because the continent-ocean transition is buried beneath thick layers of volcanic and sedimentary rocks ${ }^{5,6}$ and the tectonic activity that characterized breakup has ceased. Instead, the timing of these mechanisms is inferred from theoretical models or from the geological record preserved at the fully developed, ancient rifted margins ${ }^{1,5,7,8}$. Ongoing rifting in Ethiopia offers a unique opportunity to address these problems because it exposes subaerially the transition between continental rifting towards the south and seafloor spreading further northward. Here we synthesize constraints on the spatial and temporal evolution of magmatism and extension in Ethiopia. We show that although intrusion of magma maintains crustal thickness during the early stages of the continent-ocean transition, subsidence of the margin below sea level, and eruption of voluminous basalt flows, is initiated by late-stage thinning of the heavily intruded, weakened plate just before the onset of seafloor spreading. We thus conclude that faulting, stretching and magma intrusion are each important, but at different times during breakup.
\end{abstract}

The development of ancient magmatic rifted margins is often thought to be the result of an anomalously hot mantle, but the timing and rate of plate stretching are also expected to effect melt generation ${ }^{7}$. Ethiopia is an ideal study locale for continental breakup because it exposes subaerially several stages of tectonically active rift sector development from embryonic rifting in the south, to incipient oceanic spreading in $\mathrm{Afar}^{9}$ (Fig. 1). Seismic wavespeeds in the upper mantle beneath Ethiopia are among the slowest worldwide, with $\mathrm{P}$-waves $\sim 6 \%$ slower than in normal mantle ${ }^{10}$. This observation has led recent studies of mantle structure to conclude that continental breakup is occurring above arguably the hottest mantle on Earth ${ }^{10}$. The ability to study the physical state of the mantle in Ethiopia is a distinct advantage over studies at ancient rifted margins, where the competing influences of elevated temperatures, small-scale convection, and a fertile mantle can be inferred only from the geological record. Furthermore, at fully developed margins the timing of extension by either magma intrusion or mechanical stretching, and the timing of eruption of voluminous basaltic flows that hinder deep seismic imaging at ancient magmatic margins (the so-called seaward dipping reflectors (SDRs)) cannot be established unambiguously, and it is here that we seek improvement.

Rifting of Arabia from Africa above the hot Ethiopian mantle initiated on border faults of the Afar Depression 29-26 Myr ago ${ }^{11}$. Extension shifted thereafter to narrower zones of small-offset faults, fissural flows and subsurface dike intrusion that marked the locus of strain until at least $7 \mathrm{Myr}$ ago ${ }^{11}$. Numerous geological, geophysical and geochemical studies have illuminated the distribution, style and timing of extension and magmatism associated with rifting in Ethiopia. However, here we synthesize along-strike variations in rifting style since Pliocene times in the Afar Depression that provide fundamental new constraints on the temporal evolution of magmatism and extension, and their implications for the formation of ancient magma-rich margins.

A striking observation in Fig. 2 is the lack of crustal thinning in the rift between $9.5^{\circ}-13^{\circ} \mathrm{N}$ (refs 12,13) compared with that predicted by traditional stretching models ${ }^{14}$ using crustal thinning as a proxy for plate thinning. Plate reconstructions ${ }^{15}$ predict $\beta$-factors (the ratio between initial and final crustal thickness) of $\sim 3$, but seismic data in southern $\mathrm{Afar}^{13}$ indicate $\beta \approx 1.7$. Seismic experiments, complemented by gravity analysis, illuminate high-velocity, dense, igneous crustal intrusions beneath the rift in this region ${ }^{13,16}$. The present-day observations of dike injection during the ongoing Dabbahu rifting episode show that principally magma intrusion, rather than faulting and ductile stretching, is the cause of extension in this section of the rift, and repeated dike intrusion episodes can reproduce the rift morphology ${ }^{17}$. In support of these geological and geodetic constraints, studies of 40 years of global seismicity records show that seismic moment release from earthquakes in Afar contributes less than $50 \%$ of the total geodetic moment predicted from plate separation rates ${ }^{18}$. This has the implication that aseismic extensional mechanisms such as dyke injection are now the principal mechanism of strain between Africa and Arabia.

The observations from Ethiopia join a growing body of evidence from theoretical and observational studies of rifts that show magma intrusion plays a key role during breakup ${ }^{19,20}$. They are also consistent with seismic studies of buried magmatic margins that image thick, high seismic velocity zones of crustal intrusions ${ }^{5}$, but without a constraint for the timing of emplacement. Accommodating extension by magma intrusion without marked plate thinning has the implication that stretching factors during the early stages of continent-ocean transition (COT) development will be relatively low. This, in turn, dramatically affects the timing and volumes of decompression melts generated by plate thinning in the mantle in the later stages of breakup. Rapid stretching during the final stages of the COT, at the expense of extension by magma intrusion, would be expected to produce a pulse of decompression melt in the asthenosphere that would not be predicted if thinning of the plate was achieved gradually since the onset of breakup ${ }^{7}$. Note the relative paucity of Quaternary-Recent volcanism in Ethiopia south of $13^{\circ} \mathrm{N}$ where the crust is relatively thick: evidence for dike intrusion is pervasive, but voluminous young basaltic flows are absent $^{21,22}$ (Fig. 2). How then, and when, do the voluminous basalt flows- the so-called SDRs_-form above the COT?

\footnotetext{
${ }^{1}$ Department of Earth Sciences, University of Bristol, Bristol, BS8 4RJ, UK, ${ }^{2}$ School of Earth and Environment, University of Leeds, Leeds, LS2 9JT, UK.

†Present address: National Oceanography Centre, University of Southampton, Southampton, SO14 3ZH, UK. *e-mail: ian.bastow@bristol.ac.uk.
} 


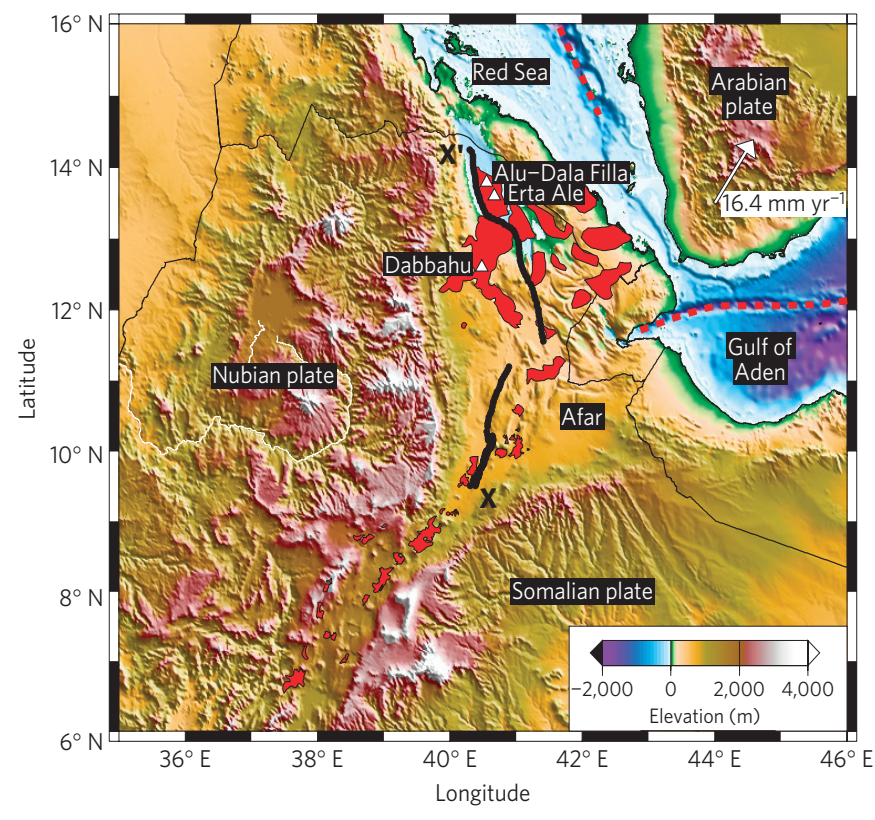

Figure 1 | Topography and bathymetry in the Horn of Africa. Black lines $\left(X-X^{\prime}\right)$ are the locations of seismic wide-angle experiments used to constrain crustal thicknesses shown in Fig. 3. The white triangles are volcanoes. Areas shaded red are Quaternary-Recent basaltic volcanism. The arrow shows the motion of the Arabian plate relative to Africa. Dashed red lines are seafloor spreading centres in the Red Sea and Gulf of Aden.

Moving along-strike in the rift into northern Afar, Fig. 2 shows an abrupt thinning of the crust to $<15 \mathrm{~km}$, coincident with subsidence of the land towards and below sea level, and a marked pulse of Quaternary-Recent basaltic volcanism. Uppermost mantle velocities of $7.4-7.5 \mathrm{~km} \mathrm{~s}^{-1}$ in this region are lower than are typically found $\left(\geq 7.8 \mathrm{~km} \mathrm{~s}^{-1}\right)$ beneath the Moho elsewhere on Earth. Makris and Ginzburg ${ }^{12}$ cite this as evidence for elevated temperatures beneath Afar, a conclusion corroborated by the markedly slow mantle seismic velocities imaged by teleseismic tomography ${ }^{10}$. Studies of plate motions in Afar indicate that Arabia has rifted away from Africa at present-day rates since $\sim 13 \mathrm{Myr} \mathrm{ago}^{23}$, so the pulse of volcanism observed in Fig. 2 cannot be explained easily by an increase in extension rate. As further evidence arguing against an increased extension rate for the pulse in volcanism, we note that extensional velocities derived from GPS measurements do not vary substantially along the rift in this region of $\mathrm{Afar}^{23}$, yet we see dramatic along-strike variations in the amount of Quaternary-Recent volcanism.

Although we cannot preclude the possibility that the thinning of the crust (and by inference the lithosphere) in northern Afar occurred gradually since the onset of rifting, the previously uncorrelated observations in Fig. 2 can be explained well by a phase of recent decompression melting owing to rapid localized stretching of the heavily intruded plate. In support of the recent stretching hypothesis, constraints on the stratigraphy of the Danakil basin indicate that it is filled by up to $\sim 3 \mathrm{~km}$ of Pliocene-Recent age evaporates and basalt flows ${ }^{24}$, suggesting that rapid subsidence of the region towards and below sea level is no older than $\sim 5 \mathrm{Myr}$. Constraining this phase of plate stretching to recent times has the implication that larger volumes of melt can be produced than if thinning had been achieved more gradually over the $\sim 30 \mathrm{Myr}$ since breakup began: slow stretching allows cooling to the surface by conduction without the production of appreciable melt volumes ${ }^{7}$.

Observations of reduced effective elastic plate thickness in northernmost Afar to $\sim 5 \mathrm{~km}$ compared with $\sim 9 \mathrm{~km}$ farther south ${ }^{25}$, along with the spatial coincidence of voluminous young volcanism

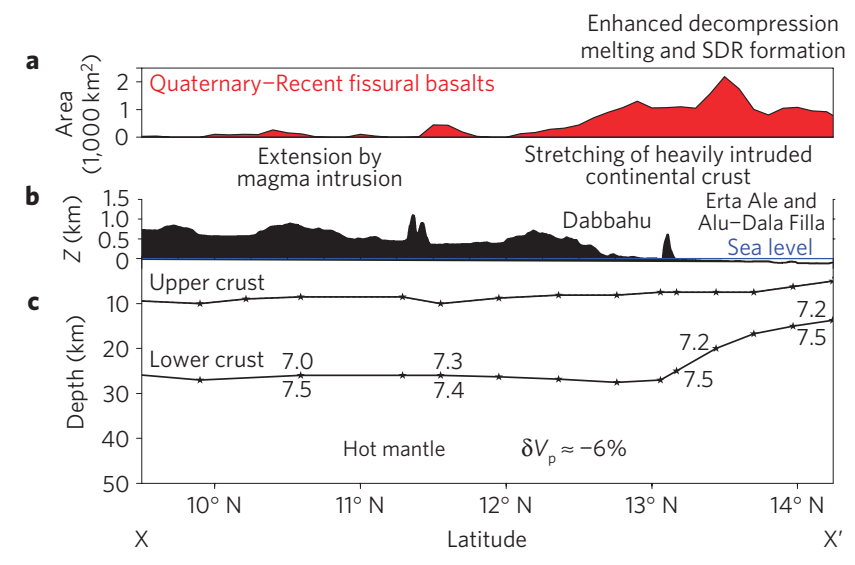

Figure 2 | Rift structure and volcanism in Ethiopia. Variations in Quaternary-Recent basaltic volcanism (see for example, refs 21,22 and Fig. 1) exposed every $0.1^{\circ}$ latitude along the profile (a), elevation (b) and crustal thickness $^{12,13}(\mathbf{c})$, with latitude in Ethiopia along the profile $X-X^{\prime}$ (Fig. 1). Velocities on (c) are in $\mathrm{km} \mathrm{s}^{-1}$. Note the abrupt thinning of the crust in northern Afar $\left(>13^{\circ} \mathrm{N}\right)$, which coincides with subsidence of the margin below sea level and a marked pulse in Quaternary-Recent volcanism.

and thinned plate (Fig. 2), strongly indicate that plate weakening by heating owing to protracted and localized magma intrusion has reduced the tectonic force required for plate stretching. In this scenario, increased decompression melting in the mantle, coincident with a reduction in melt volumes participating in extension, means that larger melt volumes can extrude through the thinner and weaker plate, as is observed in northern Afar (Figs 1 and 2). The basaltic lava flows, erupting close to sea level before the onset of seafloor spreading, are progressively concealing the heavily intruded Afar crust ${ }^{26}$. The surface morphology of northern Afar shows that when erupted, these inviscid basalts typically flow up to several tens of kilometres away from topographically prominent, heavily fissured axial edifices such as Erta Ale and Alu-Dala Filla ${ }^{26}$ (Figs 1 and 2); they cover previous basaltic flows and sometimes drape over sediments (predominantly evaporites) deposited adjacent to shield volcanoes ${ }^{27}$. Once re-oriented by progressive loading of basalt flows ${ }^{28}$, high-density mafic intrusions ${ }^{11}$, and by subsidence of the young passive margin by progressive cooling of the plate and underlying asthenosphere, the young basalt flows of northern Afar will form SDRs that severely hamper high resolution imaging of the COT structure at volcanic rifted margins elsewhere ${ }^{3,6}$. Although the bulk of Afar's basalt sequences are forming during the final stages of breakup, the Miocene volcanism observed in Afar south of $13^{\circ} \mathrm{N}$ will probably form the landward edge of the final SDR sequence ${ }^{9,11}$ once breakup is complete in Afar.

Our observations from Ethiopia strongly support the view that variations in magmatism during breakup are controlled principally by the varying strength (and by inference the thermal structure) of the extending plate. Although the total volumes of magma produced during COT development are probably governed strongly by extension rate and mantle temperature ${ }^{1,7}$, our insights from Ethiopia show that temporal variations in strain partitioning between stretching and magma intrusion over time, and their consequences for plate rheology, are vital in understanding construction of the COT. The style and timing of volcanism in northern Afar is strikingly similar to that inferred, for example, from recent seismic images of the $\sim 60$-Myr-old Atlantic margin, where basaltic flows are also thought to have erupted close to sea level, just before the onset of seafloor spreading, above a stretched and heavily intruded COT in the presence of elevated mantle temperatures ${ }^{5}$. Improved constraints on the evolving locus of strain and plate strength during the development of the COT at such 
margins should thus help resolve the differences between competing model $s^{5,29,30}$ for their formation.

Active processes above the hot Ethiopian mantle show that faulting, stretching and magma intrusion are important at different times during rifting. After a protracted period of extension by magma intrusion without marked crustal thinning, plate strength is reduced sufficiently for stretching and efficient adiabatic decompression melting to recommence. The final stretching of the heavily intruded plate results in decompression melting of the asthenosphere and the eruption of voluminous basalt flows. These flows, once bent downwards by progressive loading and thermal subsidence, will form the SDRs at the newly formed magmatic rifted margin as it continues to subside below sea level. The challenge now is thus to understand better when and why faulting, stretching and magma intrusion evolve as they do during the protracted development of the COT. Combining, not isolating, these mechanisms of strain in new rifting models and appreciating how plate strength varies during rifting is essential in developing a clearer understanding of the incomplete geological record that documents continental breakup over time.

Received 10 November 2010; accepted 1 February 2011; published online 13 March 2011

\section{References}

1. White, R. \& McKenzie, D. Magmatism at rift zones: The generation of volcanic continental margins and flood basalts. J. Geophys. Res. 94, 7685-7729 (1989).

2. Holbrook, W. \& Kelemen, P. Large igneous province on the US Atlantic margin and implications for magmatism during breakup. Nature 364, 433-436 (1993).

3. Barton, A. J. \& White, R. S. Volcanism on the Rockall continental margin. J. Geol. Soc. Lond. 154, 531-536 (1997).

4. Hopper, J. et al. Structure of the SE Greenland margin from seismic reflection and refraction data: Implications for nascent spreading center subsidence and asymmetric crustal accretion during North Atlantic opening. J. Geophys. Res. 108, 2269 (2003)

5. White, R. et al. Lower-crustal intrusion on the North Atlantic continental margin. Nature 452, 460-464 (2008).

6. Mutter, J., Talwani, M. \& Stoffa, P. Origin of seaward-dipping reflectors in oceanic crust off the Norwegian margin by 'subaerial sea-floor spreading'. Geology 10, 353-357 (1982).

7. Bown, J. W. \& White, R. S. Effect of finite extension rate on melt generation at rifted continental margins. J. Geophys. Res. 100, 18011-18029 (1995).

8. Buck, W. in The Structure and Evolution of the East African Rift System in the Afar Volcanic Province (eds Yirgu, G., Ebinger, C. J. \& Maguire, P. K. H.) 43-54 (Geol. Soc. Lond. Spec. Pub., Vol. 259, 2006).

9. Ebinger, C. \& Casey, M. Continental breakup in magmatic provinces: An Ethiopian example. Geology 29, 527-530 (2001).

10. Bastow, I. D., Nyblade, A. A., Stuart, G. W., Rooney, T. O. \& Benoit, M. H. Upper Mantle Seismic Structure Beneath the Ethiopian Hotspot: Rifting at the Edge of the African Low Velocity Anomaly. Geochem. Geophys. Geosyst. 9, Q12022 (2008).

11. Wolfenden, E., Ebinger, C., Yirgu, G., Renne, P. R. \& Kelley, S. P. Evolution of a volcanic rifted margin: Southern Red Sea, Ethiopia. Geol. Soc. Am. Bull. 117, 846-864 (2005).

12. Makris, J. \& Ginzburg, A. The Afar Depression: Transition between continental rifting and sea floor spreading. Tectonophysics 141, 199-214 (1987).
13. Maguire, P. et al. in The Afar Volcanic Province within the East African Rift System (eds Yirgu, G., Ebinger, C. J. \& Maguire, P. K. H.) 271-293 (Geol. Soc. Lond. Spec. Pub., Vol. 259, 2006).

14. McKenzie, D. Some remarks on the development of sedimentary basins. Earth Planet. Sci. Lett. 40, 25-32 (1978).

15. Eagles, G., Gloaguen, R. \& Ebinger, C. J. Kinematics of the Danakil microplate. Earth Planet. Sci. Lett. 203, 607-620 (2002).

16. Keranen, K., Klemperer, S., Gloaguen, R. \& EAGLE Working Group, Three-dimensional seismic imaging of a protoridge axis in the main Ethiopian rift. Geology 32, 949-952 (2004).

17. Wright, T. et al. Magma-maintained rift segmentation at continental rupture in the 2005 Afar dyking episode. Nature 442, 291-294 (2006).

18. Hofstetter, R. \& Beyth, M. The Afar Depression: Interpretation of the 1960-2000. Geophys. J. Int. 155, 715-732 (2003).

19. Thybo, H. \& Nielsen, C. Magma-compensated crustal thinning in continental rift zones. Nature 457, 873-876 (2009).

20. Calais, E. et al. Strain accommodation by slow slip and dyking in a youthful continental rift, East Africa. Nature 456, 783-788 (2008).

21. Chernet, T., Hart, W., Aronson, J. \& Walter, R. New age constraints on the timing of volcanism and tectonism in the northern Main Ethiopian Rift-southern Afar transition zone (Ethiopia). J. Volcanol. Geotherm. Res. 80, 267-280 (1998).

22. Mazzarini, F. Vent distribution and crustal thickness in stretched continental crust: The case of the Afar Depression (Ethiopia). Geosphere 3, 152-162 (2007).

23. ArRajehi, A. et al. Geodetic constraints on present-day motion of the Arabian Plate: Implications for Red Sea and Gulf of Aden rifting. Tectonics 29, TC3011 (2010).

24. Hutchinson, R. W. \& Engels, G. G. Tectonic evolution in the southern Red Sea and its possible significance to older rifted continental margins. Geol. Soc. Am. Bull. 83, 2989-3002 (1972).

25. Ebinger, C. J. \& Hayward, N. J. Soft plates and hot spots: Views from Afar. J. Geophys. Res. 101, 21859-21876 (1996).

26. Barberi, F. \& Varet, J. The Erta Ale volcanic range (Danakil depression, northern Afar, Ethiopia). Bull. Volcanol. 34, 848-917 (1970).

27. Bonatti, E., Emiliani, C., Ostlung, G. \& Rydell, H. Final desiccation of the Afar rift, Ethiopia. Science 172, 468-469 (1971).

28. Palmason, G. A continuum model of crustal generation in Iceland: Kinematic aspects. J. Geophys. 40, 7-18 (1980).

29. Van Wijk, J. W., Huismans, R. S., Ter Voorde, M. \& Cloetingh, S. Melt generation at volcanic continental margins: No need for a mantle plume. Geophys. Res. Lett. 28, 3995-3998 (2001).

30. Armitage, J. J., Collier, J. S. \& Minshull, T. A. The importance of rift history for volcanic margin formation. Nature 465, 913-917 (2010).

\section{Acknowledgements}

We thank L. Baker, the EAGLE working group, and staff at the Institute of Geophysics, Space Science and Astronomy, Addis Ababa University for discussions. Thanks to C. Ebinger and C. Hawkesworth for advice in the early stages of writing of the manuscript. Reviewers R. England and G. Manatschal provided constructive comments that helped improve the focus of the contribution. I.D.B. was funded by the Leverhulme Trust. D.K. was funded by NERC fellowship NE/E013945/1.

\section{Author contributions}

I.D.B. and D.K. both developed the scientific concepts presented herein, and jointly wrote the paper. I.D.B. created the figures.

\section{Additional information}

The authors declare no competing financial interests. Reprints and permissions information is available online at http://npg.nature.com/reprintsandpermissions. Correspondence and requests for materials should be addressed to I.D.B. 